\title{
Characteristics of an outpatient chronic hepatitis $B$ virus infection cohort
}

\author{
Caracterização de uma coorte ambulatorial de pacientes \\ com infecção por vírus da hepatite $B$ crônica
}

\author{
Danyenne Rejane de Assis ${ }^{1}$, Simone de Barros Tenore ${ }^{1}$, João Renato Rebello Pinho ${ }^{2}$, \\ David Salomão Lewi ${ }^{1}$, Paulo Roberto Abrão Ferreira ${ }^{1}$
}

\begin{abstract}
Objective: To characterize a chronic hepatitis B cohort based on initial and follow-up clinical evaluations. Methods: A retrospective and descriptive analysis of clinical and laboratory data from chronic $\mathrm{HBs} \mathrm{Ag}$ adult carriers, without HIV, unexposed to treatment, with at least two outpatient visits, between February 2006 and November 2012. Fisher's exact test, $\chi^{2}$, Wilcoxon, Spearman, multiple comparisons and Kappa tests were applied, the level of significance adopted was $5 \%$, with a $95 \%$ confidence interval. Results: 175 patients with mean age of $42.95 \pm 12.53$ years were included: $93(53.1 \%)$ were men, $152(86.9 \%)$ were negative for hepatitis $\mathrm{B}$ e-antigen $(\mathrm{HBeAg}), 3(1.7 \%)$ had hepatitis C coinfection, 15 (8.6\%) had cirrhosis, and 2 (1.1\%) had hepatocellular carcinoma. Genotype A predominated. Sixty-six patients (37.7\%) had active hepatitis, $6(3.4 \%)$ presented immune tolerance, and $38(21.7 \%)$ were inactive carriers. Exacerbations and/or viral breakthrough were detected in 16 patients $(9.1 \%)$. In 32 patients (18.3\%), hepatitis B virus DNA remained persistently elevated and alanine aminotransferase levels were normal, whereas in $17(9.7 \%)$, there was low hepatitis B virus DNA and alterated alanine aminotransferase. If only initial alanine aminotransferase and hepatitis B virus DNA values were considered, 15 cases of active hepatitis would not have been detected. Advanced fibrosis was more common in $\mathrm{HBeAg}$-positive patients, and it was significantly associated with transaminases, hepatitis $B$ virus DNA, and age. Conclusion: Many patients had active hepatitis, but almost $25 \%$, who were $\mathrm{HBeAg}$ non-reactive, were only identified because of combined analyses of the hepatitis B virus DNA and transaminases levels, sometimes associated with histological data, after clinical follow-up.
\end{abstract}

Keywords: Hepatitis B, chronic; Hepatitis B/therapy; Natural history; Hepatitis B e antigens

\section{RESUMO}

Objetivo: Caracterizar uma coorte de pacientes com hepatite B crônica, segundo parâmetros iniciais e evolutivos. Métodos: Análise retrospectiva e descritiva dos dados clínicos e laboratoriais de portadores crônicos adultos do HBsAg, sem HIV, virgens de tratamento, com ao menos duas consultas ambulatoriais entre fevereiro de 2006 a novembro de 2012. Empregaram-se os testes exato de Fisher, $\chi^{2}$, Wilcoxon, Spearman, Kappa e comparações múltiplas, o nível de significância estatística adotado foi de $5 \%$ e intervalo de confiança de 95\%. Resultados: Foram incluídos 175 pacientes com média de idade de $42,95 \pm 12,53$ anos, $93(53,1 \%)$ do sexo masculino, $152(86,9 \%)$ não reagentes para o antígeno e $(\mathrm{HBeAg}), 3(1,7 \%)$ coinfectados com hepatite $C, 15(8,6 \%)$ cirróticos e $2(1,1 \%)$ com carcinoma hepatocelular. Predominou 0 genótipo A. Constataram-se hepatite ativa em 66 pacientes $(37,7 \%)$, imunotolerância em $6(3,4 \%)$, estado de portador inativo em $38(21,7 \%)$, exacerbações e/ou escapes virais em 16 (9,1\%). Em 32 (18,3\%), havia DNA viral persistentemente elevado e alanina aminotransferase normal; em $17(9,7 \%)$, carga viral constantemente baixa e alanina aminotransferase alterada. Se fossem considerados apenas transaminases e DNA viral iniciais, 15 casos de hepatite ativa não teriam sido evidenciados. Fibrose avançada foi mais prevalente em HBeAg reagentes e associou-se direta e significativamente ao DNA do vírus da hepatite, idade e transaminases. Conclusão: Grande parte dos pacientes apresentou hepatite ativa. Porém, aproximadamente um quarto (todos pertencentes ao grupo $\mathrm{HBeAg}$ não reagente) foram identificados somente em função da análise conjunta das mensurações sequenciais de DNA do vírus da hepatite e transaminases, por vezes aliada a dados histológicos, após seguimento.

Descritores: Hepatite B crônica; Hepatite B/terapia; História natural; Antígenos $\mathrm{E}$ da hepatite $\mathrm{B}$

\footnotetext{
1 Universidade Federal de São Paulo, São Paulo, SP, Brazil.

${ }^{2}$ Hospital Israelita Albert Einstein, São Paulo, SP, Brazil; Laboratory of Tropical Gastroenterology and Hepatology - LIM-07, Instituto de Medicina Tropical, São Paulo, SP, Brazil; Department of Gastroenterology, Faculdade de Medicina, Universidade de São Paulo, São Paulo, SP, Brazil.

Corresponding author: Paulo Roberto Abrão Ferreira - Rua Ouvidor Peleja, 235, room 101 - Vila Mariana - Zip code: 04128-000 - São Paulo, SP, Brazil - Phone: (55 11) 99173-1993

E-mail: paulo.abrao.ferreira@gmail.com

Received on: Sep 26, 2014 - Accepted on: Jan 6, 2015

Conflict of interest: none.

DOI: 10.1590/\$1679-45082015A03269
} 


\section{INTRODUCTION}

The World Health Organization estimates the existence of approximately 240 million people infected by the hepatitis B (HBV) virus in the world, and approximately 780 thousand annual deaths resulting from the infection. ${ }^{(1)}$ In Brazil, in 2010, 104,454 cases were confirmed, with a detection rate of 7.6 per 100 thousand inhabitants, which means a low to moderate incidence of the infection in the country. ${ }^{(2,3)}$

The natural history of chronic hepatitis B is characterized by four phases, not necessarily sequential or present in all cases. The initial phase, immune tolerance, is marked by reactivity of "e" antigen ( $\mathrm{HBe} A g)$, high serum levels of HBV deoxyribonucleic acid (DNA) (HBV-DNA), normal or slightly elevated alanine aminotransferase (ALT), and habitually absence of histological signs of fibrosis and inflammation. ${ }^{(4-7)}$ The second phase, immune clearance, results from the attempt to eliminate the virus; its prolonged stay increases the risk of progression to cirrhosis and hepatocelular carcinoma (HCC). There is liver inflammation, ALT elevation, and a modest reduction of the levels of HBV-DNA, culminating in the loss of the $\mathrm{HBeAg}$ and seroconversion into anti-HBe. ${ }^{(8)}$ Next is the phase of the inactive carrier, with remission of the disease, improved prognosis, and usually, improved histology. ALT levels normalize and the HBV-DNA drops $(<10$ thousand copies/mL or $2,000 \mathrm{UI} / \mathrm{mL}$ ) or becomes undetectable. ${ }^{(5)}$ However, the fourth phase may appear, with reactivation, whether spontaneous or as a result of immunosuppression, with a progression of liver damage and a new elevation of ALT and HBV-DNA. ${ }^{(8,9)}$

The identification of these phases helps in the prediction of the presence of liver damage, but in practical terms, this is a complex issue due to the dynamic character of the infection. ${ }^{(5-7,10)}$ There are few recent Brazilian studies focused on identifying the presentation forms of chronic hepatitis $\mathrm{B}$, especially those that consider the follow-up of patients with successive HBV-DNA quantifications. ${ }^{(11,12)}$

\section{OBJECTIVE}

To determine and characterize the forms of presentation of an outpatient cohort of chronic hepatitis B as per initial and follow-up parameters.

\section{METHODS}

\section{Study design and study population}

A retrospective cohort study carried out at the Infectious Diseases outpatient clinic of the Universidade Federal de São Paulo. The data were collected by review of medical records of patients admitted between February 2006 and December 2011, with follow-up until November 2012.

Patients monoinfected by HBV or coinfected by $\mathrm{HBV}$ and the hepatitis $\mathrm{C}$ virus (HCV) were screened. Included were those $\mathrm{HBs} A g$-reagent for more than 6 months, at least two outpatient visits with two collections of biochemical and molecular biology tests, a minimal follow-up of 5 months, more than 18 years of age, and with no HIV infection. Excluded were patients exposed to treatment, only one result available of ALT or HBV-DNA, and absence of a complete serum profile. The Research Ethics Committee of the Universidade Federal de São Paulo approved the study (approval number 450,995 and Certificate of Presentation for Ethical Appreciation - CAAE: 23237413.5.0000.5505).

\section{Data collection}

The following data were collected: age, comorbidities, alcohol consumption, coinfection with $\mathrm{HCV}$, transaminases, serology, HBV-DNA, genotype, liver biopsy result, and presence of clinical cirrhosis, characterized by means of signs and symptoms, laboratory and/or imaging alterations resulting from fibrosis and/or liver failure. For this, the following topics were considered: presence of ascites, encephalopathy, and other conditions, such as telangiectasia, palmar erythema, rarefication of hair in men, jaundice, gynecomastia, flapping, hyperbilirubinemia, hypoalbuminemia, and increased prothrombin time of activity, considering the total clinical picture. Moreover, presence of esophageal and/or gastric fundus varicose veins, splenomegaly, increased portal vein caliber, hepatic echotexture and morphological changes revealing a nodular parenchyma with blunt edge, with or without volume reduction. Whenever the biopsy was available, data was collected as per the METAVIR scoring system for histology activity staging, considering A0 for absent activity, A1 for mild activity, A2 for moderate and A3 for severe; and for fibrosis, considering F0 as the absence of fibrosis, F1 for portal fibrous expansion with no septa, F2 for fibrous expansion with rare septa, F3 for fibrous expansion with numerous septa, and F4 for cirrhosis.

Quantification of the HBV-DNA collected at the facility up to January 2012 was performed in-house, with the real-time polymerase chain reaction method (RT-PCR), using a minimal detection limit of $50 \mathrm{UI} / \mathrm{mL}$ and maximal of 1,000,000UI $/ \mathrm{mL}$. Later, the Abbott Real Time HBV kit (Applied Biosystems, Branchburg, NJ, United States) was used, with quantification linearity of 15 to $500,000,000 \mathrm{UI} / \mathrm{mL}$. Some patients had external tests expressed in copies $/ \mathrm{mL}$, and the conversion factor used for transformation into $\mathrm{UI} / \mathrm{mL}$ was division by 5.2 . 
For the purposes of statistical analysis, results inferior to the detection limit were expressed as zero and those above it as 11,000,000 or $7.04 \mathrm{log}$. The transaminase values considered altered were those over $30 \mathrm{U} / \mathrm{mL}$, both for ALT and for aspartate aminotransferase (AST), based on the local reference values.

\section{Definitions adopted}

An inactive carrier was considered when $\mathrm{HBeAg}$ nonreactive with normal transaminase levels, HBV-DNA $<2,000 \mathrm{UI} / \mathrm{mL}$ in all measurements, and if a liver biopsy was performed, with histologic activity present or discreet (A0 or A1). ${ }^{(4,13)}$

Immune tolerance was defined in the presence of patients who were $\mathrm{HBeAg}$-reactive, had persistently normal transaminase levels, and HBV-DNA levels over $2,000 \mathrm{UI} / \mathrm{mL}$. $^{(4,13)}$

Active hepatitis was considered if ALT was elevated and HBV-DNA was more than $2,000 \mathrm{UI} / \mathrm{mL}$ in one of two or in most of the observations. If a biopsy was available, the presence of moderate to severe periportal activity (grades 2 and 3 by METAVIR), regardless of the previously cited conditions. ${ }^{(4)}$

Viral breakthrough occurred when there were elevated levels of HBV-DNA to more than 2,000UI/mL and at least two times the baseline value. ${ }^{(4)}$

Exacerbation was considered when there was an increase greater than five times the baseline levels of transaminases, with any increase of HBV-DNA. ${ }^{(4,14)}$

\section{Statistical analysis}

Qualitative variables were expressed as absolute (n) and relative (\%) frequencies; the quantitative variables as mean, median, standard deviation, minimum, and maximum. For data analysis, the Statistical Package for the Social Sciences (SPSS) software, version 17, was used. The level of significance adopted was $5 \%$, with a 95\% confidence interval.

Fisher's exact test and $\chi^{2}$ test were used for isolated qualitative variables; Wilcoxon or Kruskal-Wallis tests for grouped variables. Spearman's test was used to verify the degree of correlation among numeric variables. For statistical differentiation between groups, multiple comparisons were used. The Kappa test was applied to measure agreement between different methods of classification.

\section{RESULTS}

Two hundred and seventy-six patients were screened, and 101 were excluded, 72 of them for having only one HBV-DNA result, 8 for having only one ALT value measured, 20 due to exposure to treatment, and 1 for not having the $\mathrm{HBeAg}$. The baseline characteristics of the 175 patients included are shown on table 1 .

Table 1. Primary characteristics of the patients selected for the study

\begin{tabular}{lc}
\hline Characteristics & $\mathbf{n}(\%)$ \\
\hline Sex & \\
Male & $93(53.1)$ \\
Female & $82(46.9)$ \\
Age (years, mean \pm SD) & $42.95 \pm 12.52$ \\
HCV coinfection & $3(1.7)$ \\
HBeAg-reagent & $23(13.1)$ \\
Cirrhosis & $15(8.6)$ \\
Hepatocellular carcinoma & $2(1.1)$ \\
\hline
\end{tabular}

SD: standard deviation; HCV: hepatitis C virus; HBeAg-reagent: reactivity to the e- antigen.

Among the 170 patients who answered about associated diseases, 115 (67.6\%) denied comorbidities and $9(5.3 \%)$ presented with more than one condition. Isolated or associated hypertension was present in $19(11.2 \%)$ cases and diabetes mellitus in $13(7.6 \%)$. Information on the consumption of alcohol was obtained in 169 patients $(96.6 \%), 132(78.1 \%)$ of them denied using alcohol, and $5(2.9 \%)$ reported abusive consumption.

The initial mean for HBV-DNA, expressed in logarithm, was $3.64 \pm 2.00 \log \mathrm{UI} / \mathrm{mL}$. The baseline median for ALT was $26.00 \pm 47.33 \mathrm{UI} / \mathrm{mL}$ in 173 patients and for AST it was $24.00 \pm 20.48 \mathrm{UI} / \mathrm{mL}$ in 164 . Most of the patients $(154 ; 88 \%)$, presented with detectable initial HBV-DNA; for $100(57.1 \%)$ of them it was more than $2000 \mathrm{UI} / \mathrm{mL}$, but there was a greater proportion of normal ALT (103 patients; 59.5\%), as per figure 1.
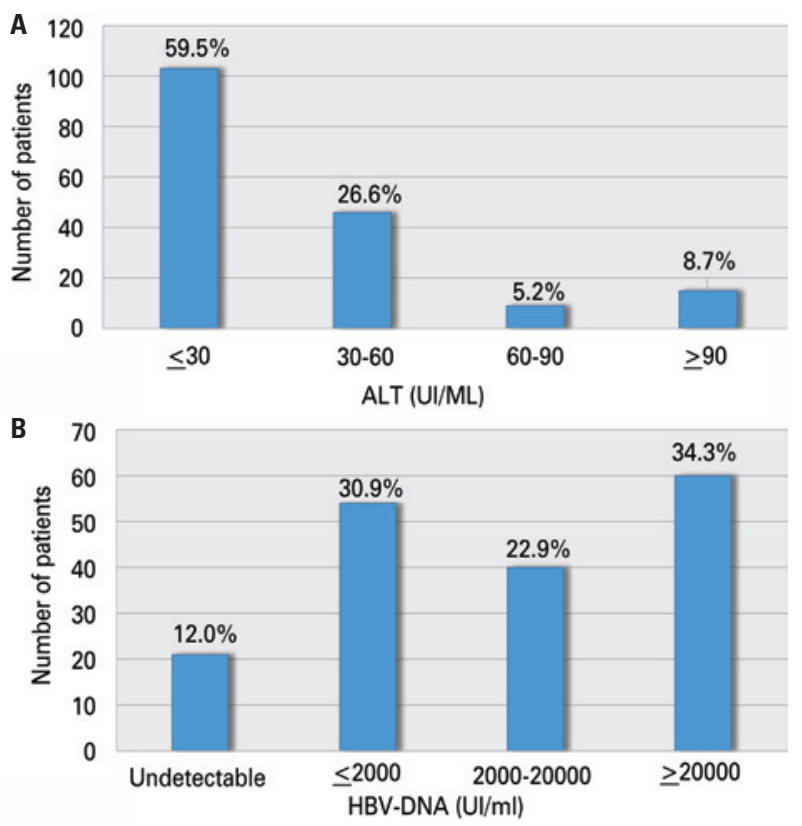

HBV-DNA: DNA of hepatitis B virus; ALT: alanine aminotransferase.

Figure 1. Distribution of patients by categories of baseline alanine aminotransferase $(A)$ and hepatitis $B(B)$ DNA values 
The genotype was identified in 64 patients (Figure 2). There was a predominance of A (41 patients; 64.1\%), with subgenotype A1 in 40 cases and A2 in 1. Genotype D was detected in 18 cases $(28.1 \%)$. Genotypes C, E, and $\mathrm{F}$ were found in $3(4.7 \%), 1(1.6 \%)$, and $1(1.6 \%)$ patients, respectively. When comparing 41 patients with genotype A to 21 with genotype $\mathrm{C}$ or $\mathrm{D}$, advanced fibrosis was identified (F3, F4, or clinical cirrhosis) in $2.4 \%$ of the former and in $14.3 \%$ of the latter, with no statistical significance $(\mathrm{p}=0.1085)$.

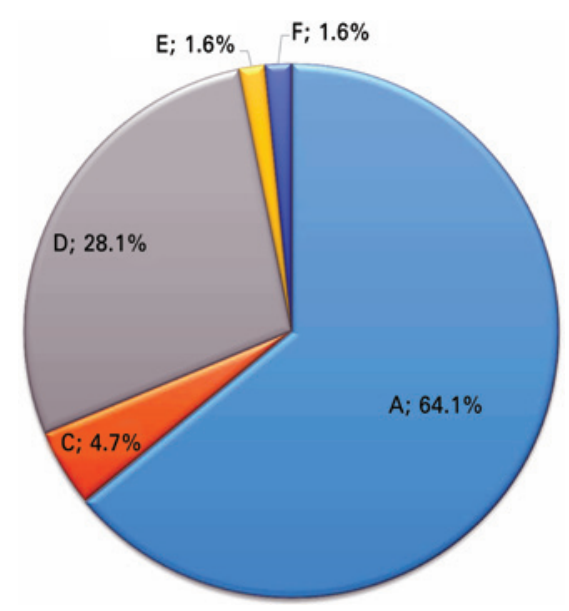

Figure 2. Distribution of the viral genotypes

Ninety-six patients were submitted to liver biopsies $(54.9 \%)$. Moderate or advanced degrees of histologic activity (A2 and A3) were detected in 39 (40.6\%) of them. Fibrosis staging was available in 93 patients, among whom $56(62.2 \%)$ presented with at least $\mathrm{F} 1$, and $11(11.8 \%)$ had advanced stages (F3 and F4).

Patients with advanced fibrosis were, on average, 10 years older than the others $(50.89 \pm 11.64$ versus $41.98 \pm 12.31$ years; $p=0.005)$ and presented with higher baseline levels of HBV-DNA (mean of $5.05 \pm 2.3$ $\log$ versus $3.47 \pm 1.9 \mathrm{log} ; \mathrm{p}=0.0009$ ), ALT (median of $44 \pm 76.82$ versus $25 \pm 42.26 ; \mathrm{p}=0.0002$ ) and AST (median of $45.50 \pm 13.77$ versus $23.00 \pm 20.44 ; p<0.0001$ ). There was also an association between advanced fibrosis and HBeAg-reagents $(p=0.027)$.

By means of Spearman's correlation test, the intensity of association between baseline HBV-DNA and ALT was measured. There was a positive correlation $(\mathrm{r}=0.44$; $\mathrm{p}<0.0001$ ), with a moderate degree (correlation intensity $-r$, between 0.3 and 0.7 ) among these variables.

Individualized analysis of the serum profile, of the set of measurements of HBV DNA/ALT, and of the histology data, whenever available, allowed the determination of the stages of the natural history of chronic hepatitis B in 110 patients $(62.9 \%)$. Six (3.4\%) presented with immune tolerance; $16(9.1 \%)$ with immune clearance or active $\mathrm{HBeAg}$-positive hepatitis; $38(21.7 \%)$ were inactive carriers, and $50(28.6 \%)$ with active $\mathrm{HBeAg}$-negative hepatitis (reactivation). In 65 patients $(37.1 \%)$ it was not possible to identify any of these phases. Therefore, the following forms of presentation were defined: one exacerbation, 15 viral breakthrough $(8.6 \%), 32(18.3 \%)$ patients with elevated HBV-DNA and persistently normal ALT, and 17 (9.7\%) with low HBV-DNA and constantly elevated ALT; among these last two types, two patients reported abusive consumption of alcoholic beverages, and two others were diabetic and had hypertension.

If in the analysis of the presentation forms we considered only the baseline values of ALT and HBV-DNA, the agreement with the abovementioned distribution would be high, i.e., $89 \%$ by the Kappa test. Nevertheless, 15 cases of active $\mathrm{HBeAg}$-negative hepatitis would be neglected ( $\mathrm{p}<0.0001)$, as is shown on table 2. Additionally, it would be impossible to predict viral breakthroughs and exacerbations.

The presentation forms were associated with HBV-DNA and sex, but not with age. The mean HBV-DNA of the 66 patients with active hepatitis (50 in a phase of reactivation and 16 in immune clearance) and of the six immune tolerant was significantly greater than the others, but similar among themselves (4.89 and 5.21, respectively). The male sex was more frequently associated with active hepatitis $(49.5 \%$ versus $24.4 \%)$ and the female gender with elevated HBV-DNA and normal ALT $(28.0 \%$ versus $9.0 \%)$, as is shown on table $3(\mathrm{p}=0.0009)$.

Table 2. Comparing the distribution of presentation forms of the disease, as per initial evaluation and after follow-up

\begin{tabular}{lccc}
\hline Classification & $\begin{array}{c}\text { Initial } \\
\text { evaluation }\end{array}$ & $\begin{array}{c}\text { Post follow-up } \\
\text { evaluation }\end{array}$ & $\begin{array}{c}\text { Agreement* } \\
\text { (\%) }\end{array}$ \\
\hline Inactive carrier & 40 & 38 & 95.00 \\
Immune tolerance & 6 & 6 & 100 \\
Active hepatitis HBeAg non- reagent & 31 & 46 & 67.40 \\
Elevated HBV-DNA and normal ALT & 45 & 32 & 71.10 \\
Immuneactivation & 15 & 15 & 100 \\
\hline
\end{tabular}

${ }^{*} p<0.0001$. HBeAg: Hepatitis $B$ e antigen; HBV-DNA: DNA of hepatitis B virus; ALT: alanine aminotransferase.

Table 3. Distribution of presentation form categories relative to sex

\begin{tabular}{lccc}
\hline \multirow{2}{*}{ Categories } & \multicolumn{2}{c}{ Sex } & \multirow{2}{*}{ p value } \\
\cline { 2 - 3 } & Male & Female & \\
\hline Active hepatitis & $46(49.5)^{*}$ & $20(24.4)^{*}$ & \\
Inactive carrier & $15(16.1)$ & $23(28.0)$ & \multirow{2}{*}{0.0009} \\
Elevated HBV-DNA, normal ALT & $9(9.7)^{*}$ & $23(28.0)^{*}$ & \\
Low HBV-DNA, altered ALT & $11(11.8)$ & $6(7.3)$ & \\
Exacerbation/viral breakthroughs & $10(10.8)$ & $6(7.3)$ & \\
Immune tolerance & $2(2.2)$ & $4(4.9)$ & \\
\hline Total & $93(100)$ & $82(100)$ & \\
\hline * $0<0$.05 in multiple comparisons (post-hoc). HBV-DNA: DNA of the hepatitis B virus: ALT: alanine aminotransferase.
\end{tabular}


Only 23 patients $(13.1 \%)$ were HBeAg-reagent, with an initial HBV-DNA mean greater than the others $(6.14 \pm 1.09 \log$ versus $3.26 \pm 1.83 \mathrm{log} ; \mathrm{p}<0.0001)$, greater medians of ALT and AST (ALT: $42.00 \pm 53.96 \mathrm{U} / \mathrm{mL}$ versus $26.00 \pm 45.78 \mathrm{U} / \mathrm{mL} ; \mathrm{p}=0.0013 ;$ AST: $38.00 \pm 26.94 \mathrm{U} / \mathrm{mL}$ versus $23.00 \pm 18.45 \mathrm{U} / \mathrm{mL} ; \mathrm{p}=0.0002)$, as per figure 3 , and a similar age mean (42.22 versus 43.06 years; $p=0.6779$ ). These also presented with a greater frequency of active hepatitis $(69.6 \%$ versus $32.9 \%, \mathrm{p}<0.0001)$ and advanced fibrosis $(26.1 \%$ versus $8.6 \%$; $\mathrm{p}=0.027$ ) than $\mathrm{HBeAg}$ nonreagent individuals (Table 4).
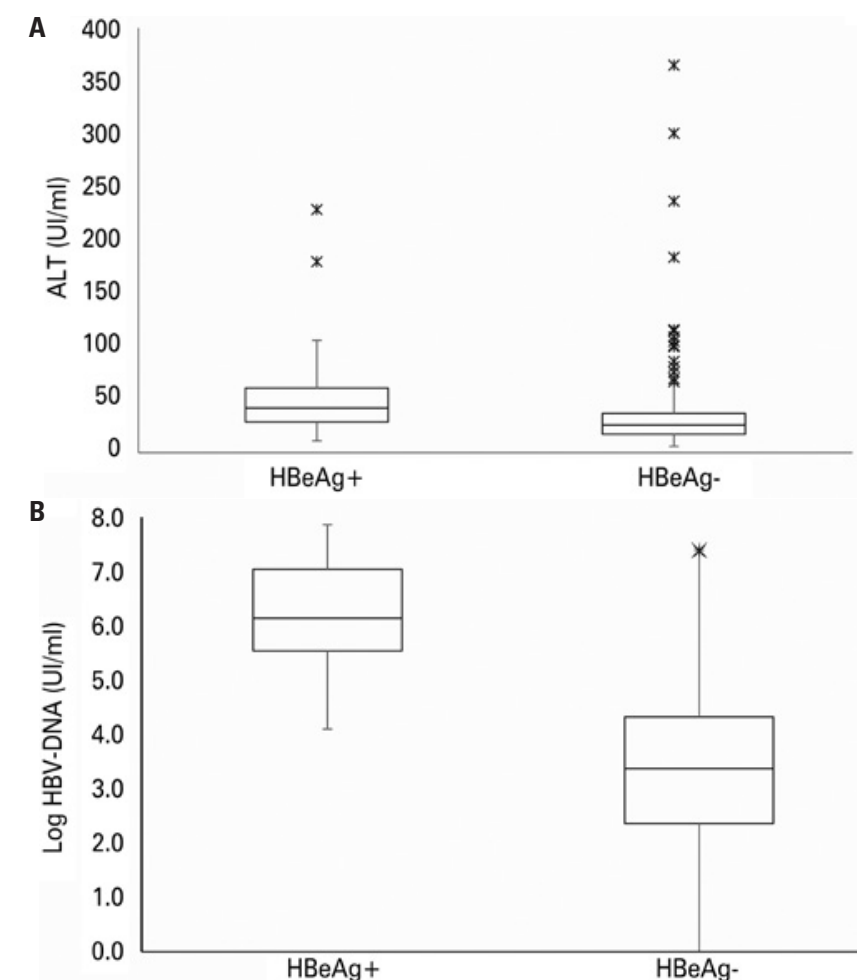

ALT: alanine aminotransferase; HBV-DNA: DNA of hepatitis B virus; $\mathrm{HBeAg}+$ : positive hepatitis (reactivation). $\mathrm{HBeAg}$ negative hepatitis (reactivation).

Figure 3. Boxplot of the initial values of aminotransferase $(A)$ and DNA of the hepatitis $B(B)$ virus as per the presence or absence of $\mathrm{HBeAg}$

Table 4. Distribution of advanced fibrosis prevalence as per the presence of the e-antigen

\begin{tabular}{|c|c|c|c|}
\hline \multirow[b]{2}{*}{ HBeAg + } & \multicolumn{2}{|c|}{ Advanced fibrosis } & \multirow[b]{2}{*}{ p value } \\
\hline & $\begin{array}{c}\text { No }(n=156) \\
n(\%)\end{array}$ & $\begin{array}{c}\text { Yes }(n=19) \\
n(\%)\end{array}$ & \\
\hline Yes & $17(10.9)$ & $6(31.6)$ & 0.0027 \\
\hline
\end{tabular}

\section{DISCUSSION}

Chronic infection with HBV is a dynamic and complex process of interaction between the virus, the hepatocytes, and the host's immune system. ${ }^{(5,15)}$ The variability in forms of presentation of the disease, both individually and collectively, represents a great challenge in patient management and in public health. ${ }^{(6,15,16)}$ Progression of the liver damage occurs primarily during the active hepatitis phase, therefore, in terms of population, it is important to identify the proportion of individuals that are in this stage.

Two large Brazilian studies demonstrated a high proportion of active hepatitis B within the population studied. One of them, conducted in the Southeastern region, found a rate of $57 \%$ among 521 patients; the other revealed $43.6 \%$ among 3,614 patients from different regions. In the latter, however, information on HBV-DNA was not available in many cases and neither study defined the presentation forms as per evolution parameters. ${ }^{(11,12)}$ Such as in these studies, patients with active hepatic disease corresponded to a large portion of our sample (about 40\%), with the difference of the classification having been carried out after clinical followup. If only initial data regarding ALT and HBV-DNA had been considered, approximately one fourth of these patients would not have been identified.

Just as has been described in literature, male patients more frequently had active hepatitis in our sample..$^{(5,10,16-18)}$ Contrary to the findings from endemic regions, where vertical transmission or early childhood acquisition predominate, ${ }^{(18,19)}$ the mean age of the individuals at different phases of the disease was similar and relatively high, which along with the small percentage of immune tolerant individuals, suggests a predominance of horizontal transmission in the population studied.

The increase in prevalence of $\mathrm{HBe} \mathrm{Ag}$ non-reagents is a worldwide tendency. A review study conducted in the Middle East described 53 to $90 \%$ prevalence of this profile. ${ }^{(20)}$ A Spanish study revealed that $87.8 \%$ of 474 patients were $\mathrm{HBeAg}$ non- reagent, a proportion described as similar to that of other Mediterranean countries. ${ }^{(21)}$ A serologic inquiry with Americans from Asian origin showed a $90 \%$ prevalence of the profile. ${ }^{(22)}$ Two Brazilian studies also demonstrated a higher frequency of $\mathrm{HBeAg}$-negative: $84.4 \%$ of 521 patients in the Southeast region and $53.4 \%$ of 1,448 patients in regional reference centers for liver diseases. ${ }^{(11,12)}$ Similarly, there was a predominance of this profile: $87 \%$ of the patients in our study.

The greatest proportion found of active hepatitis among $\mathrm{HBe} A g$-reagents was in accordance with the data from non-endemic regions. A Brazilian research project with 521 patients revealed that $72.8 \%$ of the $\mathrm{HBeAg}$ reagents presented with an immuneactive phase. ${ }^{(12)}$ An Australian study with 348 patients revealed a negligible proportion of immune tolerant individualss $(6 \%)$ within 
a minority of $\mathrm{HBeAg}$-reagent $(28 \%){ }^{(23)}$ On the other hand, a Brazilian study with 3,614 patients from the five geographical regions showed a prevalence $17 \%$ higher of active hepatitis in the $\mathrm{HBeAg}$ non-reagent. However, in evaluating the result by region, the only one with a higher rate of active disease among the $\mathrm{HBeAg}$ non-reactive was the North, which concentrates high endemicity sub-region for chronic hepatitis $\mathrm{B}^{(4,11)}$

It is known that the loss of $\mathrm{HBe} \mathrm{Ag}$ does not necessarily imply an evolution to a state of inactive carrier or improvement of the prognosis, since it may result from viral mutations that impede production of the marker, and after the event, reactivation may appear. ${ }^{(5-7,9)}$ In conformity with literature, the results of our study suggest greater unpredictability of the evolution of HBeAg non-reagent patients. Determination of the presentation forms of the disease was more complex in the presence of this serological profile, and all the divergence found by analysis of the admission and follow-up parameters occurred in this group.

The influence of genotypes on the progression and prognosis of the disease was recently shown. Genotype A is described as the most prevalent in Brazil, ${ }^{(24)}$ and was also the most frequent in our study. In a previously conducted investigation in the Brazilian Southeastern region, the $\mathrm{D}$ genotype was the second most frequent, as well as in our project. ${ }^{(25)}$ A prior Brazilian study with 53 patients showed no association among genotypes and advanced fibrosis. ${ }^{(26)}$ In our research, despite the higher percentage of this condition having been related to genotypes $\mathrm{C}$ and $\mathrm{D}$ when compared to $\mathrm{A}$, the association was not statistically significant - perhaps due to the size of the sample. On the other hand, a prior Brazilian investigation with 139 patients showed an association between advanced fibrosis and genotype $\mathrm{A}$ when compared to $\mathrm{D}$, contradicting data in literature that describes the relation of the latter with a less favorable prognosis. ${ }^{(3,27)}$ It is worth mentioning the presence of a patient with genotype $\mathrm{E}$, which is extremely rare in our midst. ${ }^{(11,12,26,28)}$

In a systematic review, the factors associated with hepatic mortality were male gender and HBV-DNA. The role of viral genotypes, as well as age, $\mathrm{HBeAg}$, and the levels of ALT, was limited and inconsistent. ${ }^{(29)}$ A prior Brazilian study found an association between advanced fibrosis and age, $\mathrm{HBeAg}$, alcohol consumption, and male sex in the population studied. ${ }^{(12)}$ In our research, the variables associated with this condition were $\mathrm{HBV}-\mathrm{DNA}$, age, $\mathrm{HBe} \mathrm{Ag}$, and transaminases.

In the Brazilian reality, many centers do not have quick molecular biology testing, and in practical terms, ALT levels are used to predict the presence of viral replication and liver damage in progress. Research done in endemic areas or not have already demonstrated the weak correlation between viral load and transaminases, ${ }^{(23,30)}$ and HBV-DNA is absolutely necessary for establishing the existence of viral multiplication. In our study, the correlation between HBV-DNA and transaminases was only moderate.

In the currently available guidelines, the recommendation is that HBV-DNA, ALT, and $\mathrm{HBeAg}$ be analyzed together and with great care for the indication of the biopsy and therapy decision making. ${ }^{(4,13,16)}$ The most recent international guides also point out the need for multiple clinical applications, with repeated measurements of transaminases and HBV-DNA for the determination of the phases of the disease and better management of the infected patient. ${ }^{(13,16)}$

Our project consisted of a real life study in which we sought to measure the difference between a local one-time approach and an evolutionary approach to characterize the forms of the disease in patients with chronic hepatitis B. The primary limitations were its retrospective character, the adoption of the same ALT reference value for male and female patients, and the performance of liver biopsy only when clinically indicated. Within this context, our results, corroborated by literature, suggest that due to the dynamism of the chronic infection by HBV, the infected patient should be continuously and carefully evaluated, as per joint analysis of the clinical, serologic, biochemical, molecular biology, and sometimes histologic parameters.

\section{CONCLUSION}

A large part of the patients presented with active hepatitis and therefore, would have indication for treatment. However, approximately one fourth of them (all $\mathrm{HBeAg}$ non-reagent) were identified only because of the joint analysis of the sequential measurements of the hepatitis B DNA and the transaminases, sometimes along with histology data, after follow-up.

\section{ACKNOWLEDGEMENTS}

This project was partially suppported by Instituto Israelita de Responsabilidade Social, Sociedade Beneficente Israelita Brasileira Albert Einstein, São Paulo, SP, Brazil.

\section{REFERENCES}

1. World Health Organization (WHO). Hepatitis B. Fact sheet No. 204 [Internet] 2014. [cited 2014 Jul 22]. Available from: http://www.who.int/mediacentre/ factsheets/fs204/en/ 
2. Brasil. Ministério da Saúde. Secretaria de Vigilância em Saúde, Departamento de DST, Aids e Hepatites Virais. Boletim Epidemiológico Hepatites Virais. Brasil, 2007-2010 [Internet]. Brasília (DF); 2011 [citado 2014 jul 21]. Disponível em: http://www.aids.gov.br/sites/default/files/anexos/publicacao/2011/50073/ boletim_hepatites2011_pdf_64874.pdf

3. Dos Anjos GR, Martins RM, Carneiro MA, Brunini SM, Teles SA. Epidemiology of hepatitis $B$ virus infection in first-time blood donors in the southwestern region of Goiás, central Brazil. Rev Bras Hematol Hemoter. 2011;33(1):38-42.

4. Brasil. Ministério da Saúde. Secretaria de Vigilância em Saúde, Departamento de DST, AIDS e Hepatites Virais. Programa Nacional para a Prevenção e 0 Controle das Hepatites Virais. Protocolo Clínico e Diretrizes Terapêuticas para o Tratamento da Hepatite Viral Crônica B e Coinfecções. Brasília, (DF): Ministério da Saúde; 2009.

5. Liaw YF. Natural history of chronic hepatitis B virus infection and long-term outcome under treatment. Liver Int. 2009;29 Suppl1:100-7. Review.

6. Fattovich G, Bortolotti F, Donato F. Natural history of chronic hepatitis B: special emphasis on disease progression and prognostic factors. J Hepatol. 2008;48(2):335-52. Review.

7. Nebbia G, Peppa D, Maini MK. Hepatitis B infection: current concepts and future challenges. OJM. 2012;105(2):109-13. Review.

8. Lin $\mathrm{CL}, \mathrm{Kao} \mathrm{JH}$. Hepatitis B viral factors and clinical outcomes of chronic hepatitis B. J Biomed Sci. 2008;15(2):137-45. Review.

9. Papatheodoridis GV, Manolakopoulos S, Liaw YF, Lok A. Follow-up and indications for liver biopsy in HBeAg-negative chronic hepatitis B virus infection with persistently normal ALT: a systematic review. J Hepatol. 2012;57(1):196-202. Review.

10. Liaw YF, Chu CM. Hepatitis B virus infection. Lancet. 2009;373(9663):582-92.

11. Galizzi FJ, Teixeira R, Fonseca JC, Souto FJ. Clinical profile of hepatitis B virus chronic infection in patients of Brazilian liver reference units. Hepatol Int. 2010;4(2):511-5.

12. Chachá SG, Ferreira SC, Costa TV, Almeida Filho LC, Villanova MG, Souza FF, et al. Clinical, demographic and epidemiological characteristics of patients with hepatitis B followed at a university hospital in southeastern Brazil: predominance of HBeAg negative cases. Rev Soc Bras Med Trop. 2011;44(1):13-7.

13. European Association For The Study Of The Liver. EASL clinical practice guidelines: Management of chronic hepatitis B virus infection. J Hepatol. 2012;57(1):167-85. Erratum in: J Hepatol. 2013;58(1):201. Janssen, Harry [corrected to Janssen, Harry LA].

14. Lin CL, Liao LY, Liu CJ, Yu MW, Chen PJ, Lai MY, et al. Hepatitis B viral factors in HBeAg-negative carriers with persistently normal serum alanine aminotransferase levels. Hepatology. 2007:45(5):1193-8.

15. Lok AS, McMahon BJ. Chronic hepatitis B: update 2009. Hepatology. 2009: 50(3):661-2.

16. Fonseca JC. [Natural history of chronic hepatitis B]. Rev Soc Bras Med Trop. 2007;40(6):672-7. Review. Portuguese.
17. Chen CJ, Yang HI. Natural history of chronic hepatitis B REVEALed. J Gastroenterol Hepatol. 2011;26(4):628-38. Review.

18. Tong MJ, Hsu L, Hsien C, Kao JH, Durazo FA, Saab S, et al. A comparison of hepatitis B viral markers of patients in different clinical stages of chronic infection. Hepatol Int. 2010;4(2):516-22.

19. Wu DL, Xu GH, Lu SM, Ma BL, Miao NZ, Lu XB, et al. Age versus clinical virological characteristics in chronic hepatitis $B$ virus infection: a case series study in China. Eur J Gastroenterol Hepatol. 2012;24(4):406-13.

20. Specialist Panel on Chronic Hepatitis B in the Middle East. A review of chronic hepatitis B epidemiology and management issues in selected countries in the Middle East. J Viral Hepat. 2012;19(1):9-22. Review.

21. Gómez Rodríguez R, Guardiola Arévalo A, Gómez Moreno AZ, García Vela A, Gómez Hernando C, Rodríguez Merlo R, et al. [Characteristics of patients with chronic hepatitis B virus infection. Analysis of a series of 474 patients] Gastroenterol Hepatol. 2013;36(4):243-53. Spanish.

22. Xu JJ, Tien C, Chang M, Rhee J, Tien A, Bae HS, et al. Demographic and serological characteristics of Asian Americans with hepatitis B infection diagnosed at community screenings. J Viral Hepat. 2013;20(8):575-81.

23. Croagh CM, Bell SJ, Locarnini S, Desmond PV. Assessment of chronic hepatitis B: the importance of hepatitis B virus DNA testing. Intern Med J. 2012;42(2):170-5.

24. Devesa M, Pujol FH. Hepatitis B virus genetic diversity in Latin America. Virus Res. 2007;127(2):177-84. Review.

25. Tonetto PA, Gonçales NS, Fais VC, Vigani AG, Gonçales ES, Feltrin A, et al. Hepatitis B virus: molecular genotypes and $\mathrm{HBeAg}$ serological status among HBV-infected patients in the southeast of Brazil. BMC Infect Dis. 2009;9:149.

26. Becker CE, Mattos AA, Bogo MR, Branco F, Sitnik R, Kretzmann NA. Genotyping of hepatitis $B$ virus in a cohort of patients evaluated in a hospital of Porto Alegre, South of Brazil. Arq Gastroenterol. 2010;47(1):13-7.

27. Malmström S, Eilard A, Larsson SB, Hannoun C, Norkrans G, Lindh M. Genotype impact on long-term virological outcome of chronic hepatitis $B$ virus infection. J Clin Virol. 2012;54(4):321-6.

28. Pereira LM, Martelli CM, Merchan-Hamann E, Montarroyos UR, Braga MC, de Lima ML, Cardoso MR, Turchi MD, Costa MA, de Alencar LC, Moreira RC, Figueiredo GM, Ximenes RA; Hepatitis Study Group. Population-based multicentric survey of hepatitis $B$ infection and risk factor differences among three regions in Brazil. Am J Trop Med Hyg. 2009;81(2):240-7.

29. Taylor BC, Yuan JM, Shamliyan TA, Shaukat A, Kane RL, Wilt TJ. Clinical outcomes in adults with chronic hepatitis B in association with patient and viral characteristics: A systematic review of evidence. Hepatology. 2009;49/5 Suppl):S85-95.

30. Shao J, Wei L, Wang H, Sun Y, Zhang LF, Li J, et al. Relationship between hepatitis B virus DNA levels and liver histology in patients with chronic hepatitis B. World J Gastroenterol. 2007;13(14):2104-7. 